\title{
Piotr Sękowski
}

Uniwersytet Łódzki

\section{Perswazja a argumentacja. Czy skuteczność argumentu idzie $w$ parze z logiczną poprawnościa?}

\section{Wyjaśnienie}

Przedmiotem niniejszego artykułu jest analiza wzajemnych relacji między logiczną poprawnością a skutecznością argumentacji. Problematyka związana z teorią argumentacji jest bardzo szeroka, a jej historia sięga starożytności. Nie jest moim celem historyczny wykład problemu, ale refleksja w oparciu o wybrane współcześnie aktualne teorie. $Z$ jednej strony możemy zagadnienia te rozważać z perspektywy logicznej, która pozwala na analizę kwestii poprawności argumentów, z drugiej strony niepodobna pominąć ujęcie psychologiczne, które pozwala zrozumieć mechanikę skuteczności argumentów. Zważywszy na temat artykułu uwzględnienie obu perspektyw wydaje się szczególnie uzasadnione.

Pociąga to za sobą oczywiście pewne niedogodności. Jeśli wziąć pod uwage zakres poruszanej problematyki, a zarazem skromne ramy, w jakich winien zmieścić się artykuł naukowy, trzeba ograniczyć się jedynie do zasygnalizowania pewnych problemów, tym bardziej że celem tego tekstu nie jest rozważenie żadnego szczegółowego pytania, ale zagadnienia relacji między poprawnością a skutecznością argumentów. Problem ten zakłada przekrojowe, ale szerokie ujęcie tematu.

Z tego względu w artykule nie przedstawiam żadnej teorii i wyników w sposób wyczerpujący, a jedynie przywołuję takie elementy cytowanych koncepcji i rozstrzygnięć, które pozwalają na jasną 
analizę postawionego problemu. Czytelnika bardziej zainteresowanego odsyłam do pozycji wyliczonych w bibliografii, w których znajdzie dużo bardziej szczegółowe opracowanie niektórych kwestii, jak również dalsze wskazania bibliograficzne odsyłające bezpośrednio do pozycji wysoce specjalistycznych.

\section{Wstęp}

Trudno wyobrazić sobie życie społeczne bez komunikacji. Ta z kolei wydaje się pociągać za sobą konieczność argumentacji. Z komunikacją mamy do czynienia $w$ życiu zawodowym, towarzyskim, rodzinnym. Komunikacja odgrywa ogromną rolę na każdym poziomie interakcji społecznej i $w$ każdej jej postaci - od intymnego kontaktu sam na sam, na randce, w cztery oczy, po życie polityczne; $w$ interakcji formalnej i nieformalnej [por. Giddens 2006 : 722]. Na każdym z poziomów, które rozciągają się między oboma biegunami (intymnym a ogólnospołecznym), komunikacja wiąże się również z wywieraniem wpływu na inne osoby. Wpływ na drugą osobę wywiera chłopak zabiegający o względy dziewczyny, rodzic tłumaczący dziecku, że dokuczanie innym jest zachowaniem niewłaściwym, sprzedawca zapewniający, że jego jabłka są najsmaczniejsze i niepryskane, fizyk referujący wyniki swoich badań, matematyk przedstawiający dowód nowego twierdzenia innym matematykom. Tak więc nieodzowna w życiu jest nie tylko prosta komunikacja, polegająca na przekazywaniu sobie informacji na temat faktów, ale i wywieranie wpływu wydaje się towarzyszyć nam na każdym kroku.

\section{Argumentacja}

Odwołując się do potocznego sposobu posługiwania się słowem „argument”, możemy stwierdzić, że argument to jakieś zdanie, które ma stanowić uzasadnienie wygłaszanego (względnie 
milcząco zakładanego) przez nas poglądu. W Słowniku Współczesnego Języka Polskiego czytamy, że jest to „dowód potwierdzający lub obalający sąd o czymś" [Wierzbicka 1998: 23]. Chcąc to wyjaśnić bardziej ściśle, możemy stwierdzić, że „z argumentem mamy do czynienia wtedy, gdy jako uzasadnienie poglądu T przedstawiane są jakieś zdania $P_{1}, P_{2}, \ldots, P_{n}$; zdania te nazywa się przesłankami, zaś zdanie T - konkluzją argumentu" [Szymanek 2008: 37]. Ideałem argumentu jest rozumowanie dedukcyjne, czyli takie, które daje nam gwarancję prawomocności wniosku, jeśli tylko wolne będzie od błędu formalnego i materialnego [por. Tokarz 2006: 129]. Przykładem takiego rozumowania jest następujące zdanie: „Każdy kawaler jest nieżonatym mężczyzną, Tomasz nie ma żony, a zatem Tomasz jest kawalerem". W takim przypadku rzeczywiście mówić możemy o argumencie, że jest dowodem (zgodnie z propozycją słownikową). Niestety poza dowodami $w$ obrębie nauk formalnych (logiki i matematyki) trudno o tego rodzaju wnioskowania, zwłaszcza w myśleniu potocznym, dlatego nie można argumentu nazywać dowodem sensu stricte.

Marek Tokarz wylicza trzy kryteria oceny argumentacji - formalne, praktyczne i ekonomiczne. Kryterium formalne mówi nam, że argumentacja jest poprawna, kiedy jest poprawna materialnie - wszystkie przesłanki argumentacji są prawdziwe - i formalnie - wniosek wynika z przesłanek. Kryterium praktyczne stwierdza, że argumentacja jest poprawna w sensie praktycznym, jeśli wszystkie wykorzystane przesłanki są do zaakceptowania, a wniosek jest dostatecznie uzasadniony przez przesłanki. Kryterium ekonomiczne mówi, że argumentacja jest nieekonomiczna, kiedy zawiera taką przesłankę, której usunięcie nie zmniejszyłoby stopnia uzasadnienia wniosku [por. Tokarz 2006: 139-140].

Kryterium formalne jest bardzo wymagające. Rozumowanie, które mu sprosta, będzie rozumowaniem dedukcyjnym (dowodem). Jak wspomnieliśmy, w potocznym myśleniu i mówieniu radko mamy do czynienia $z$ rozumowaniami dedukcyjnymi. Dlatego roztropniejsze (choć nieco mętne) wydaje się kryterium praktyczne. Możemy więc powiedzieć, że argumentacja jest 
praktycznie poprawna, kiedy prawdopodobieństwo tezy pod wpływem przesłanek wzrasta na tyle, by przyjąć tezę, przesłanki zaś nie budzą zasadniczych wątpliwości. Każdy argument spełniający kryterium formalne implicite spełnia kryterium praktyczne, ale nie odwrotnie. Ponieważ potocznie formułowane rozumowania spełniają zwykle jedynie kryterium praktyczne, stąd należy wnosić, że argumentacja poza dyskursem specjalistycznym ma charakter uprawdopodobniający, a nie dowodowy. Dokładniejsze omówienie relacji między argumentacją a dowodzeniem znajduje się w klasycznej pracy Zygmunta Ziembińskiego Logika praktyczna [2006: 211-212].

Z punktu widzenia logiki oczywiście argument spełniający jedynie kryterium praktyczne (bez formalnego), jest rozumowaniem gorszej próby od tego, które uczyniło zadość również kryterium formalnemu. Jednak trzeba mieć na uwadze, że oczekiwania użytkowników języka względem potocznej argumentacji nie są aż tak wygórowane, jak te sformułowane $w$ kryterium formalnym oceny argumentacji. Wobec tego niezmiernie ważne jest, by przy ocenie argumentacji brać pod uwagę kontekst, w jakim została ona wypowiedziana i dystynktywne cechy myślenia naukowego i potocznego, bo choć rozumowania potoczne nie mają na celu podważania rozumowań naukowych, to zachowują swoistą odrębność i kierują się sobie właściwymi regułami [por. Hołówka 1986: 51-56].

Łatwo też zauważyć, że o ile kryteria formalne i praktyczne są kryteriami warunkującymi poprawność rozumowania, o tyle kryterium ekonomiczne nie mówi nic o poprawności - argument nieekonomiczny może być poprawny. Przykładem poprawnego nieekonomicznego rozumowania jest następujące zdanie: „u jest kwadratem, ponieważ - $\mathrm{x}$ jest prostokątem, $\mathrm{x}$ ma cztery boki, boki te są równe, $x$ ma cztery kąty, kąty te są równe, każdy z kątów jest kątem prostym, x ma równe przekątne, przekątne te przecinają się pod kątem prostym dokładnie w połowie długości, $x$ jest rombem równokątnym" - zamiast tego wystarczy powiedzieć " $\mathrm{n}$ jest kwadratem, ponieważ - r jest prostokątem, x ma równe boki", bądź „n jest kwadratem, ponieważ jest rombem równokątnym”. 
Redundancja zbioru przesłanek $w$ pierwszym rozumowaniu nie szkodzi oczywiście jego poprawności, ale niewątpliwie umniejsza jego ekonomiczności.

\section{Perswazja}

Perswazja to „świadome użycie znaków i symboli, a zwłaszcza pisanego i mówionego słowa, obrazu itp. w celu wywarcia wpływu na czyjeś przekonania, postawy i decyzje" [Szymanek 2008: 228]. Nie potrzeba wnikliwych analiz, żeby zrozumieć, na czym polega zasadnicza różnica miedzy argumentacją a perswazją. Argumentacja jest prezentacją rozumowania uzasadniającego głoszoną tezę, perswazja zaś to wywieranie wpływu na odbiorcę $w$ celu zmiany jego przekonań i postępowania. Przynajmniej teoretycznie można sobie wyobrazić argumentację wolną od elementów perswazyjnych - kiedy palacz spyta mnie, czemu nie palę, odpowiem, że to szkodliwe i będzie to argument, ale nie będzie on obliczony na zmianę postawy pytającego. Niemniej $w$ większości przypadków argumentacja zawiera pierwiastki perswazyjne. Zazwyczaj argumentujemy po to, by kogoś do czegoś przekonać.

W połowie lat osiemdziesiątych Richard E. Petty i John T. Cacioppo sformułowali teorię ELM (Elaboration Likelihood Model) opisującą mechanikę procesu perswazji. Ramy tego artykułu nie pozwalają na szczegółową jej prezentację, istotne dla nas jest tylko wyjściowe twierdzenie tej teorii, mianowicie, że „(...) przekaz perswazyjny dociera do odbiory dwoma zasadniczo odmiennymi torami: centralnym i peryferyjnym" [Tokarz 2006:230]. Oznacza to, że wpływ na czyjeś przekonania i postawy wywrzeć można, odwołując się do rozsądku odbiorcy (tor centralny) lub do jego emocji i szeroko rozumianych odczuć (tor peryferyjny). Tor centralny odpowiada za racjonalne przetwarzanie informacji. Tor peryferyjny natomiast wiąże się z wszelkimi czynnikami pozamerytorycznymi i pozaracjonalnymi, jak np. ton głosu, kontekst, humor odbiorcy, mowa ciała etc. 


\section{Manipulacja}

Warto zauważyć, że o ile w zasadzie każdy argument ma charakter $w$ jakimś stopniu perswazyjny, o tyle nie każdy rodzaj perswazji ma strukturę argumentu. Kanałem, przez który argumentacja dociera do odbiorcy, jest tor centralny przekazu perswazyjnego. Argumentacja, przynajmniej we wzorcowej swej postaci, to czynność racjonalna - formułuje się ją w nadziei na przede wszystkim racjonalne odczytanie i analizę. Natomiast wpływ na prekonania i postawy odbiorcy może zostać wywarty nie tylko torem centralnym, ale i peryferyjnym. W takim przypadku mamy do czynienia ze stricte niemerytorycznym oddziaływaniem na odbiorcę. Na drodze oddziaływania torem peryferyjnym wykorzystane zostają emocje i wszelkie niewerbalne sposoby komunikacji, a także czynniki związane z kontekstem, w jakim komunikacja ma miejsce. O ile emocje są zjawiskiem, które sobie uświadamiamy, choć słabo nad nimi panujemy, o tyle odbiór i odpowiedź na inne formy komunikacji niewerbalnej, a także pozostałe czynniki związane raczej z kontekstem komunikacji, niż z samą komunikacją, pozostają (jeśli brak nam stosownego treningu) praktycznie poza obrębem naszej świadomości i władzą naszej woli.

W typowej, uczciwej sytuacji komunikacyjnej werbalne porozumienie i komunikacja niewerbalna są ze sobą silnie sprzężone i komunikaty niewerbalne nadawane są z grubsza adekwatnie do formułowanych komunikatów werbalnych. Może jednak zdarzyć się tak, że więzy między werbalnym i niewerbalnym aspektem komunikacji ulegają rozluźnieniu, np. kiedy świadomie formułuje się fałszywe komunikaty werbalne, a przy tym operuje się aspektem niewerbalnym komunikacji $w$ taki sposób, jakby komunikat werbalny był prawdziwy. W takiej sytuacji mamy do czynienia z manipulacją. Manipulacja bowiem jest chwytem komunikacyjnym wykorzystującym „bodźce obliczone na reakcje nie całkiem świadome (lub całkowicie nieświadome)" [Tokarz 2006: 294]. 


\section{Autorytet}

Ciekawym przykładem argumentu, na podstawie którego można rozważyć zależność między poprawnością a skutecznością argumentacji, jest argument $z$ autorytetu. Niezwykle szczegółową i wnikliwą analizę autorytetu przedstawił Józef Bocheński. Definiując autorytet $w$ jego najogólniejszym rozumieniu pisał, że „P jest autorytetem dla $\mathrm{S} w$ dziedzinie D wtedy i tylko wtedy, kiedy S przyjmuje $w$ zasadzie wszystko, co mu P podaje do wiadomości, a co należy do dziedziny D" [Bocheński 1974: 204]. Oznacza to, że dla kogoś profesor biologii jest o tyle autorytetem $w$ dziedzinie biologii, o ile ta osoba skłonna jest przyjąć to co ów profesor w dziedzinie biologii ma do powiedzenia.

Argument $z$ autorytetu $w$ swej idealnej postaci jest rozumowaniem o następującej strukturze: „n jest ekspertem $w$ danej dziedzinie; n twierdzi, że y; y należy do tej dziedziny; zatem y" i wykorzystuje autorytet jako eksperta $w$ danej dziedzinie. Jeśli spełnione zostaną stosowne warunki (pozwalające twierdzić, że osoba wskazywana jako autorytet $w$ danej dziedzinie rzeczywiście na to miano zasługuje i godna jest zaufania), argument taki może stać się argumentem dedukcyjnym.

Autorytet ma jednak drugie, ciemne oblicze, które ukazał amerykański psycholog Stanley Milgram. Przeprowadził on bardzo głośny eksperyment, który pokazał, jak dalece ludzie skłonni są ulec wpływowi autorytetu. W eksperymencie zaaranżowano sytuację, w której badany miał uczyć innego człowieka par słów na pamięć. Za każdą złą odpowiedź badany miał razić ucznia kolejnymi coraz silniejszymi dawkami elektrowstrząsów. Nad całością czuwał eksperymentator (autorytet). Oczywiście uczeń nie był reczywiście rażony prądem, ale odgrywał swoją rolę, czego badany nie był świadom. Okazało się, że pod wpływem nacisków eksperymentatora $65 \%$ badanych zdecydowało się zaaplikować uczniowi najsilniejszy elektrowstrząs o sile 450 woltów, mimo że na przełączniku uruchamiającym elektrowstrząsy były informacje, że są to dawki śmiertelne [por. Milgram 1963]. 
Jak zatem widać, autorytet jest potężnym narzędziem perswazji, jeśli zostanie odpowiednio wykorzystany. Mimo że argument z autorytetu może mieć postać dedukcyjną, a zatem wyłącznie racjonalną, stosunek ludzi do autorytetów jest nacechowany emocjonalnie. Z tego też względu niezwykle trudno oddzielić element racjonalny od emocjonalnego $w$ argumentacjach z autorytetu. Z autorytetami wiąże się ponadto efekt aureoli - skłonni jesteśmy być posłuszni autorytetom również $w$ dziedzinach, w których ten autorytet im nie przysługuje. Wykorzystywanie tej skłonności przez nadawców przekazu lub podmiot autorytetu to nadużycie autorytetu co do dziedziny [por. Bocheński 1974: 228-229] i jako takie jest praktyką manipulacyjną. Z drugiej strony poddanie się takiemu wpływowi wskazuje na brak roztropności.

\section{Skuteczność a poprawność}

Czy zatem poprawność może iść w parze ze skutecznością? Oczywiście tak. Wyobraźmy sobie sytuację, w której argumentujący wskazuje w sposób jak najbardziej uczciwy i rzetelny na autorytet, który odbiorca darzy ogromnym uznaniem (o czym argumentujący nie ma pojęcia). Taka argumentacja będzie zarazem poprawna i skuteczna. Trzeba jednak zwrócić uwagę, że taka sytuacja może okazać się w pewnych wypadkach niesymetryczna - argumentujący postępuje w sposób racjonalny - rzetelnie i z dbałością o intelektualną uczciwość wskazuje na autorytet i nim się podpiera, natomiast odbiorca może działać w sposób daleki od racjonalizmu - może ulec argumentowi ze względu na emocjonalny stosunek do cytowanego autorytetu. Mimo to można uznać, że argument taki spełnia oba kryteria - poprawności i skuteczności. Skuteczny jest $w$ sposób oczywisty, a poprawny dlatego, że sprostał logicznym kryteriom poprawności, bez względu na to, czy odbiorca jest tego świadom. W takiej sytuacji argumentacja jest rzetelna i perswazja udana. 
Argument skuteczny oczywiście nie musi być poprawny. (Osobnego namysłu wymagałaby tu kwestia, czy niepoprawny argument to jeszcze argument?) Pozostańmy przy podobnego rodzaju przykładach - jeśli argumentacja zawiera logiczne braki, ale argumentujący korzysta z niej wiedząc, że odbiorca darzy cytowany autorytet szczególnym uznaniem, wtedy argumentacja będzie wadliwa logicznie, ale skuteczna.

W pewnych sytuacjach skuteczność będzie wynikiem logicznej poprawności - kiedy na sympozjum matematyków jeden z uczonych predstawia poprawny dowód nieudowodnionego dotąd twierdzenia, wtedy jego argumentacja zostanie najprawdopodobniej uznana bez względu na uśmiech czy jego brak u prelegenta, bez względu na atrakcyjność formy, w jakiej zostanie przedstawiona. W życiu codziennym trudno jednak wyobrazić sobie podobną sytuację, w której wpływ wszelkich peryferyjnych czynników zostałby tak dalece zminimalizowany. Sytuacji tej nie da się odwrócić - poprawność nigdy nie wynika ze skuteczności argumentu.

\section{Perswazja a argumentacja}

Zatem należy przyjąć, że skuteczność może iść $w$ parze z poprawnością. Zbiór komunikatów będących poprawnymi argumentami i zbiór bodźców będących skutecznymi środkami perswazji mają pewną niepustą część wspólną. Argumenty formułujemy zwykle z zamysłem przekonania kogoś do czegoś, ale także dokładając $w$ miarę możliwości starań o ich rzetelność. Wykorzystujemy tym samym oba tory perswazji - centralny i peryferyjny. Jak pokazałem, sytuacja taka może sprostać wymogom komunikacyjnej uczciwości, a więc obok skuteczności gwarantować też poprawność. Niemniej z punktu widzenia logicznego wszelkie zabiegi pozamerytoryczne, kierowane na tor peryferyjny, są bezwartościowe i w interesie odbiorcy jest dokładać w miarę możliwości starań, by nie poddawać się oddziaływaniu na tym torze. 


\section{Bibliografia}

Bocheński J. M. [1974], Co to jest autorytet?, [w:] Bocheński J. M. [1993], Logika i filozofia. Wybór pism, PWN, Warszawa.

Giddens A. [2006], Socjologia, PWN, Warszawa.

Hołówka T. [1986], Myślenie potoczne, PIW, Warszawa.

Milgram S. [1963], Behavioral study of obedience, ,Journal of Abnormal and Social Psychology", 67/4.

Szymanek K. [2008], Sztuka argumentacji. Słownik terminologiczny, PWN, Warszawa.

Tokarz M. [2006], Argumentacja, perswazja, manipulacja, GWP, Gdańsk.

Wierzbicka E. (red.) [1998], Słownik Współczesnego Języka Polskiego, t. 1, „Przegląd Reader's Digest", Warszawa.

Ziembiński Z. [2006], Logika praktyczna, PWN, Warszawa. 